\title{
THE CIRCULAR ECONOMY: EUROPEAN SITUATION AND RESPONSES
}

\author{
Ruffini Alessandra
}

April 2020

\section{INTRODUCTION}

The United Nations' Department of Economic and Social Affairs estimated the actual world population of 7.6 billion can reach 9.8 billion in 2050 (see United Nations Department of Economics and Social Affairs, 21 June 2017, [19]).

The actual economic system, which should "manage fairly and sustainably limited resources", , can't support this population increase because it's a 'take-make-dispose' economy which uses limited available resources without considering future generations, neither the planet.

The main problem is that it's generally cheaper to buy the product that has a worse impact on its environment than the equivalent product that does less harm (see Chouinard Yvon et al, 2011, [4]). The reason is that costs to planet are negative externalities of difficult computation and since firms are not held accountable for their activities, these costs will not be translated into higher prices for customers.

This situation changed only in the last decades when terms like sustainability, true cost accounting, and socially responsible investing (SRI), etc... started to be used.

Today, people are more conscious of sustainability relevance, industries are studying greener solutions and Governments are creating laws and setting goals to improve green-footprints. Furthermore, in the last few years a new concept, that may help, was born: the "circular economy", where products can obtain a second life at the end of their first product-lifecycle.

This paper reports on the advances and efforts in action across the EU with respect to the sustainability of our production and consumption systems. By considering recent evidence, it also draws on some critical aspects, which will require urgent intervention in the near future.

In 2014, Florin Bonciu ${ }^{2}$ described the large-scale implementation of the circular economy in the European Union and which benefits can be obtained by facing the ineluctable changes.

Reinier de Man and Henning Friege ${ }^{3}$, in 2016 described the last policy created by the European Commission entitled "Circular Economy Closing the Loop" and proposed a sustainable resource management, backed up by multiple strategies, to face the practical problems that can be found in the policy implementation,

\footnotetext{
${ }^{1}$ See Econation, Sustainable Economy at www.econation.co.nz/sustainable-economy/

${ }^{2}$ Bonciu Florin, The European Economy: From a Linear to a Circular Economy, Romanian Journal of European Affairs, Vol. 14, N. 4, December 2014. Avaible at: https://heinonline.org/HOL/LandingPage?handle=hein.journals/rojaeuf14\&div=31\&id=\&page= ${ }^{3}$ Reinier de Man, Henning Friege, Circular Economy: European policy on shaky ground, Waste Management \& Research, Vol. 34, pages 93-95, January 2016. Available at: https://journals.sagepub.com/doi/full/10.1177/0734242X15626015
} 
Despite what has been implemented, in 2018 Julian Kirchherr ${ }^{4}$, together with other authors, discussed that little effort has been done, due also to European barriers: they are mainly cultural and the concept itself covers niches in professional discussions.

We start by describing what is waste, which possible solutions are available, where we are now, to understand how far we have moved, which "circular economy" solutions have been implemented and what future deserves us.

\section{Types of waste and their critical aspects}

The European Union describes waste as "any substance or object which the holder either discards, intends to or is required to discard" (see Article 3 of Directive 2008/98/EC [6]).

According to its origin and hazardousness, waste can be divided into three major categories:

The first one is hazardous waste, which is anything that represents the characteristics described in Annex III of Waste Framework Directive 2008/98/EC. It's originated by hazardous materials contained into products and, because of the risks they can cause, they must be indicated on products' labels.

The second category regards e-waste. It can be defined as the "electronic equipment used by businesses and individual consumers that are nearing the end of their usefulness and whose disposal is difficult because certain components contain hazardous materials" ${ }^{\prime 5}$ like cathode ray tubes in computers.

Even if many of them can be sold to someone else, given to a charity, refurbished to give them a new life or recycled, today, e-waste has a high growth rate because electronics have a very short useful life. According to Haque (2019), "in 201441.8 million tons of electronic waste (e-waste) was discarded worldwide, with only 10 to 40 percent of disposal done properly". The situation hasn't improved in 2016 when 44.7 million metric tonnes of e-waste were generated globally: it's almost like 4.500 Eiffel towers (see Baldé et al., 2017 [2]) and, according to EPA, the current e-waste recycling rate is just at 12.5\% (see Haque, 2019 [10]).

Finally, the third class is municipal solid waste (MSW). As described by the European Environment Agency, it "is mainly produced by households, though similar wastes from sources such as commerce, offices and public institutions are included. The amount of municipal waste generated consists of waste collected by or on behalf of municipal authorities and disposed of through the waste management system" (see European Environment Agency, 2013 [7]).

Municipal solid waste is the major kind of waste, which has to be taken into consideration primarily. Its composed by four macro-classes easily identifiable: plastics, bio-waste, metals and glass.

\footnotetext{
${ }^{4}$ Julian Kirchherr, Laura Piscicelli, Ruben Bour, Erika Kostense-Smit, Jennifer Muller, Anne Huibrechtse-Truijens, Marko Hekkert, Barriers to the Circular Economy: Evidence from the European Union (EU), Ecological Economics, Vol. 150, pages 264-272, August 2018. Available at: https://www.sciencedirect.com/science/article/abs/pii/S0921800917317573

${ }^{5}$ See The environmental literacy council at https://enviroliteracy.org/environment-society/waste-management/what-iswaste/
} 


\section{Plastic}

It is the major component. Its mass production started in 1950s with 2 million tonnes per year and it increased exponentially since then: in fact, by 2015 the production covered the mass of $2 / 3$ of the world population (see Ritchie and Roser, 2018 [17]), with a short downturn in 2009-2010 caused by the 2008 global financial crisis.

As the following figure illustrates (see Jambeck et al., 2015 [11]), in 2015 China used the largest amount (almost 60 million tonnes) and was followed by United States with 38 million tonnes.

Figure 1 - Public waste generation 2010

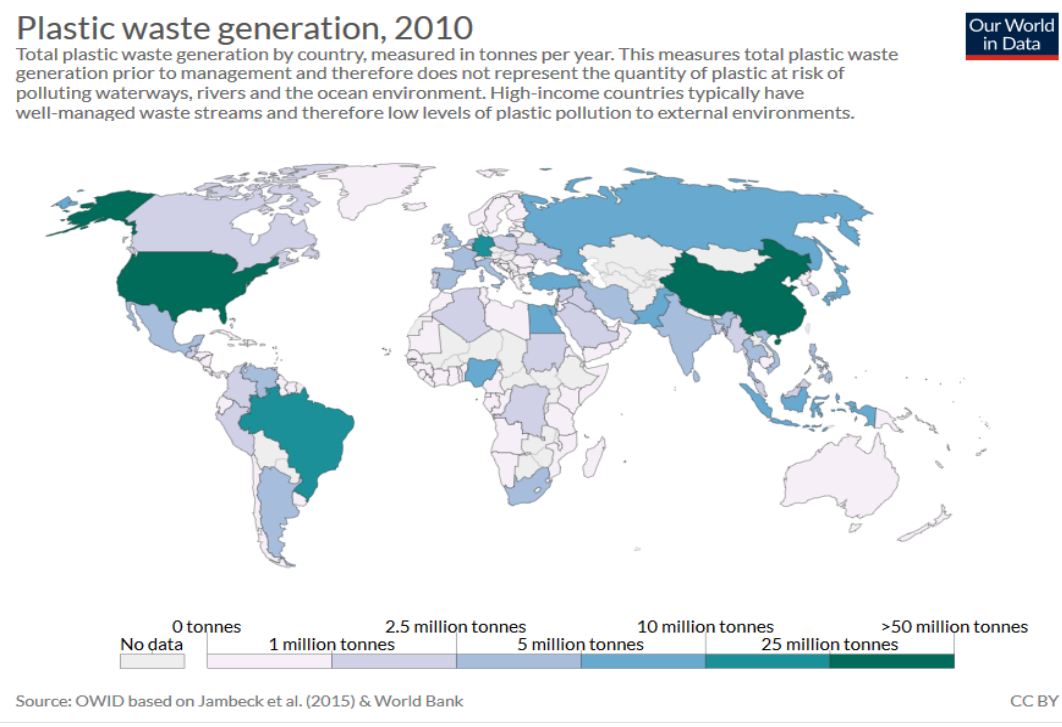

This huge amount of plastic must be managed at the end of its life cycle. Different disposal methods were implemented from 1980 to 2015 (see Geyer et al., 2017 [8]): until 1980, 100\% of plastics were discarded and only recently recycling and incineration have been used. The projections of 2050 waste disposal, as indicated by Geyer et al. (2017 [8]) highlights how the percentages of incineration and recycling are likely to increase at 50 and $44 \%$ respectively while the discarded amount may fall to $6 \%$.

Figure 2 - Projected share of global mismanaged plastic waste in 2025

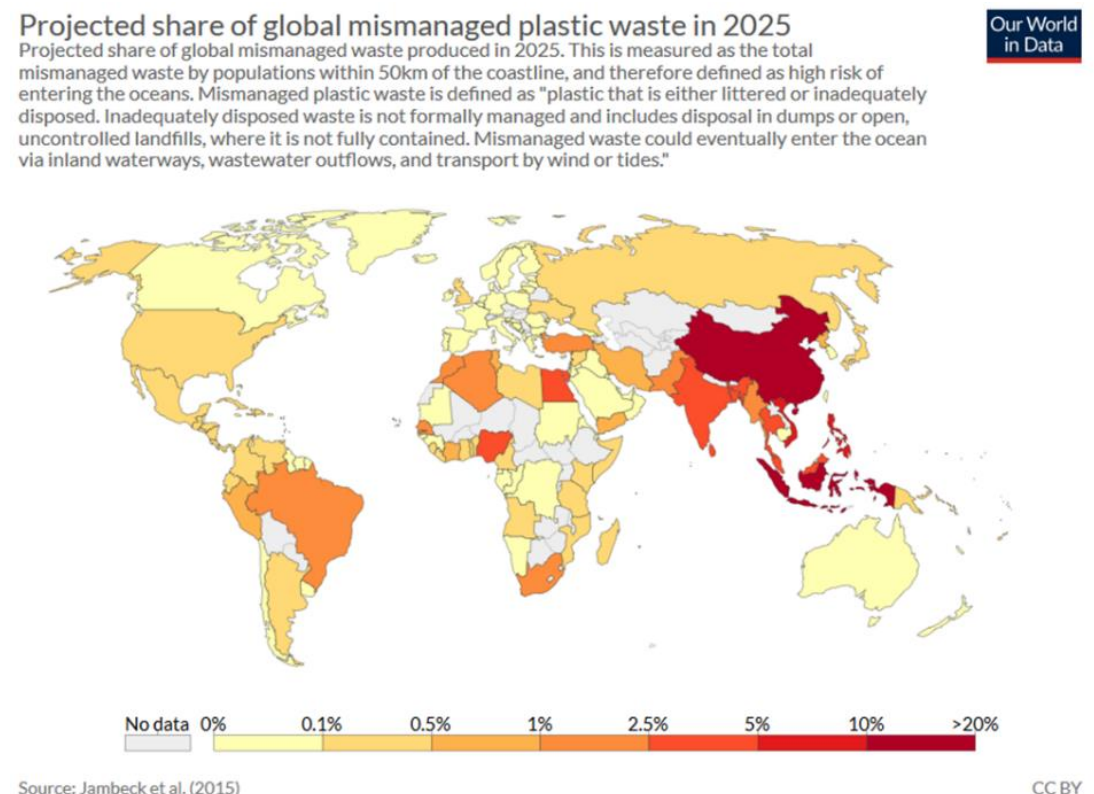


A feedback about the future of plastics can be obtained through the work done by Jambeck et al. (2015 [11]), who projected the mismanaged plastic waste production for the year 2025 (see Figure 2). From their analysis, one can deduce that by 2025: China will slightly reduce the amount of landfilled plastics with an estimate of approximately $2 \%$, East Asia will maintain the $60 \%$ of total contribution and, while Sub-Saharan Africa's share will slightly increase, the other regions' quota (America, Middle East, North Africa and Europe) of mismanaged plastic waste production will fall in relative terms.

\section{Bio waste}

Another type of MSW is bio-waste, which is defined as "biodegradable garden and park waste, food and kitchen waste from households, restaurants, caterers and retail premises and comparable waste from food processing plants" from the European Commission (see Directive 2008/98/EC [6]). Bio-waste can be assumed to account for the $40 \%$ of the total municipal waste $^{6}$, and every year the European Union produces between 118 and 138 million tonnes, of which only $25 \%$ is effectively recycled into high-quality compost and digestate (see COM/2010/235 [5]).

Figure 3 - Status on separate collection of biowaste in Europe

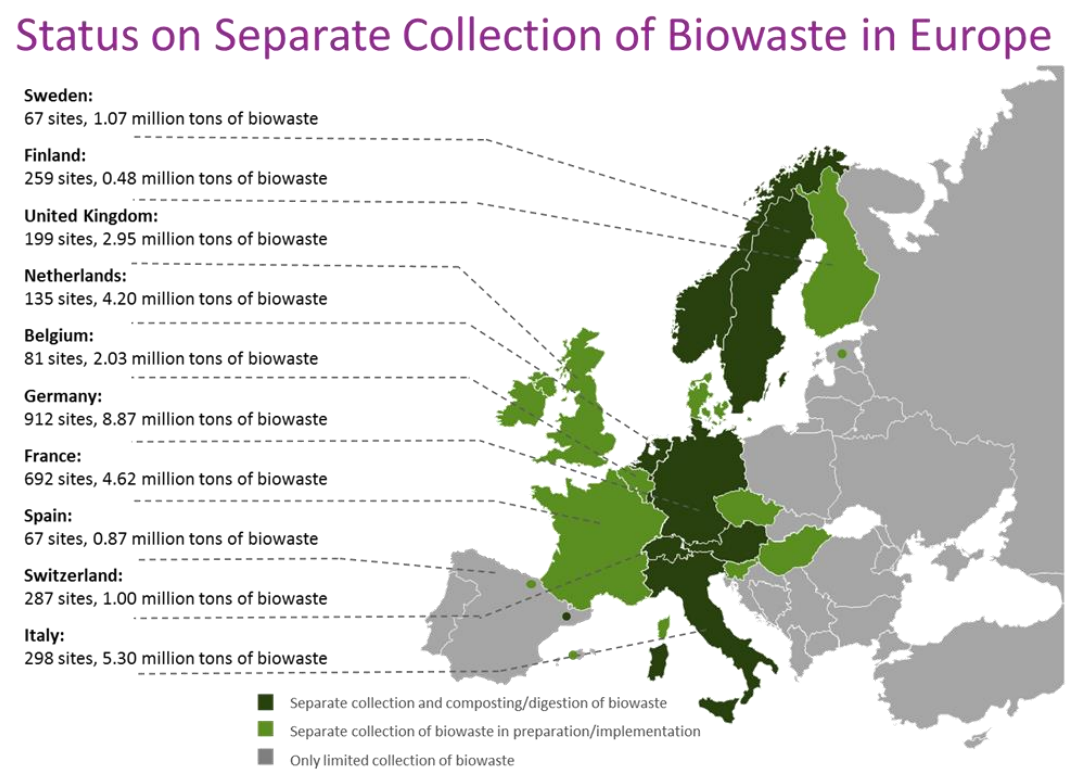

Bio-waste collection did not improve over the last years with respect to the final disposal: in 2014 a survey of the European Compost Network highlights that only 1/3 of bio-waste was separately collected, composted or digested in the European Union, with the exclusion of food residues (which total 41 million tonnes, see European Compost Network, 2014 ).

This disappointing result is caused by the differences across European Countries in separate collection and treatment capacity (see the following figure). In order to mitigate this problem, different solutions are taking place: starting from the UN 17 SDGs, which promote responsible consumption and production in sustainable cities and communities, to the Circular Economy package implemented by the European Union.

${ }^{6}$ Data available in EUROSTAT municipal waste database at http://ec.europa.eu/eurostat/data/database 
In circular economy, bio-waste obtains a new value because it's a resource for organic soil improvers, fertilisers and bio-based products. In fact, the carbon and nutrients can be extracted and transformed into a wide range of bio-based products that replace fossil-based products, like the figure up here shows.

\section{Figure 4 - Biological cycle in the circular economy}

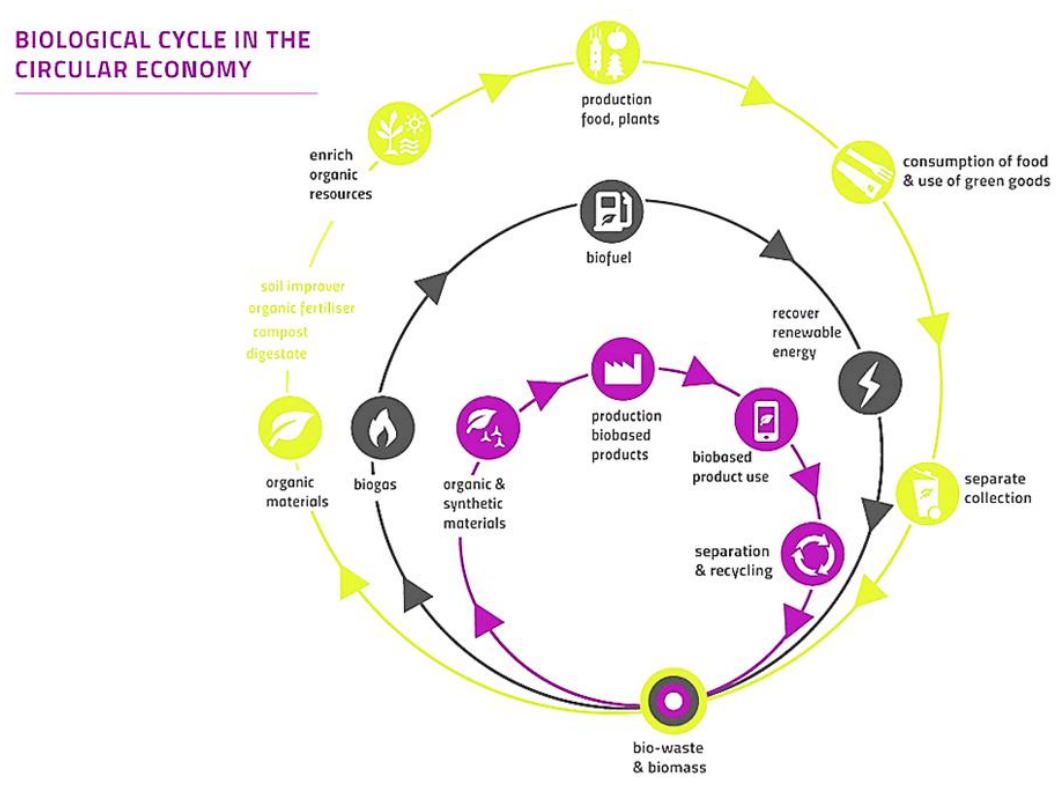

\section{Metals}

Metals are valuable materials that can be recycled repeatedly without altering their properties. They are widespread components of everyday products.

They are recycled for four main reasons: first, they don't lose their properties in being disposed; second, they generate financial gains by reselling scrap metal; third, cost-savings from the lower use of energy in their disposal process; fourth, the environmental necessity of preserving natural resources.

Despite the properties and the huge amount used every day, only $30 \%$ is recycled every year worldwide (see LeBlanc, 2018 [13]). Considering its characteristics and the benefits, this percentage is not acceptable, and it must be improved through the redesign of metal products to reduce their complexity, public awareness and community recycling programs.

\section{Glass}

Finally, among the MSW we recall glass. It is another material that can be recycled over and over without losing its properties. It's obtained from shaping the melted mixture of sand, soda ash, limestone and cullet that was heated at 2600/2800 degrees Fahrenheit. Moreover, $90 \%$ of recycled glass is used in new glass containers, kitchen-floor tiles, counter tops and insulation.

In 2011, America created 11.5 tons of glass waste but only $28 \%$ was recycled. This percentage could be higher ${ }^{7}$ because recycling glass has many benefits. First, it protects the environment because $\mathrm{CO}_{2}$ emissions can decrease up to $45 \%{ }^{8}$ and eventual discarded components can be recycled themselves. Moreover, glass can be melted infinite times without losing quality but saving costs in the process, instead of using new raw materials.

\footnotetext{
${ }^{7}$ See Pegex Hazardous waste experts at https://www.hazardouswasteexperts.com/five-tips-for-recycling-glass/

${ }^{8}$ See Ferver website at http://www.ferver.eu/en/why-recycle-glass
} 
Furthermore, glass recycling process is fast: starting as a recycling bin, a glass container arrives on a store shelf in something like 30 days (see LeBlanc, 2019 [14]).

Some communities have implemented curbside collection programs which are a service implemented in urban and suburban areas to dispose household waste collected from containers prescribed by the municipality. Some cities have also machines where people can put inside bottles to provide water and food for stray dogs.

\section{Dismantling and recovery processes}

Depending on the waste types, different processes can be applied for their dismantling and recovery. The dismantling of MSW can be done in different ways. The most common processes adopted for glass and plastics are:

1. Landfilling

2. Incineration

3. Recycling

Each of them is characterized by different levels of "greenity" and environmental sustainability.

\section{Landfilling}

Over the last few decades, landfills replaced dumping. They are "disposal sites for materials through burial" (see Ritchie, 2018) and they are regulated from siting to filling and closing: modern landfills compact waste to increase density and stability and cover it up to prevent pests. They have safeguards to control the facility and pipes to vent or incinerate the gases generated by organic waste decomposition, before they diffuse into the ground, increasing the risk of explosion; furthermore, these gases can be stored to generate electricity. According to the European Union Waste Management Hierarchy, landfilling is the least preferable option and should be limited. Even if waste is covered with soil, landfills still have negative environmental impacts. First, greenhouse gases like methane and carbon dioxide, generated when organic matter decomposes, contribute to climate change (if the landfill has pipe as described before, their impact can be limited). Second, decomposing materials can produce leachate which is any polluted liquid that contaminates the surrounding environment if not properly contained through protective lining. Third, not handled correctly PVC (polyvinil chloride), can produce additives and plasticiser compounds which leach in the soil.

\section{Incineration}

The second alternative is incineration. At the beninning, waste was burnt to decrease its volume (today, the decrease is up to $90 \%$ ) but now waste-to-energy facilities have been developed: here, the combustion process generates heat, steam and electricity.

Incineration has some arguments that support it. For example, today there is a greater control of emissions, both governmental and technical, and the bottom ash is non-injurious, so it can be landfilled or recycled, fine particles are removable using filters and scrubbers and the waste-to-energy plants can substitute power generation plants of other sort. Furthermore, high temperatures can destroy toxic materials of medical waste. However, incineration still produces carbon dioxide, which is the primary cause of global climate change, and toxic emissions that are dangerous for human and ecosystem health.

Its net impact depends on the efficiency of energy recovery process and of the facility: across Europe it's low 
because there aren't shared standards, and open burning is still common. If end-of-pipe treatment, selective catalytic reduction and suitable inhibitors have been implemented toxic emissions can be mitigated.

The first recycling practices date back to the $18^{\text {th }}$ century with the rag-picking where scavengers collected rags and used papers to obtain fiber. After that, recycling gained relevance during WWII, because metal and paper were useful, but it was then set aside until late 1960s with growing environmental movements.

\section{Recycling}

It is defined as "any recovery operation by which waste materials are reprocessed into products, materials or substances whether for the original or other purposes. It includes the reprocessing of organic material but does not include energy recovery and the reprocessing into materials that are to be used as fuels or for backfilling operations" (see Directive 2008/98/EC [6]).

Recycling, together with more effective material design, can reduce the volume of raw materials required and the toxic waste produced to have cleaner land, air, water and as a ultimate benefit, overall better health. Notwithstanding, recycling rates have started a steady increase only in the $21^{\text {st }}$ century to face the traditional disposal fees increases: in 200682 million tons of MSW was recycled in the US, reducing carbon emissions of nearly 50 million metric tons; it's the equivalent of removing 39.4 million cars from the road 9 .

Among these three alternatives, the preferred one is recycling because it's the one that decreases waste and produces other valuable goods.

As reported in a report of Material Economics of 2018 [15], "in an ambitious scenario, as much as 296 million tons CO2 per year in the EU by 2050, out of 530 Mt in total - and some 3.6 billion tonnes per year globally. Making better use of the materials that already exist in the economy thus can take EU industry halfway towards net-zero emissions. Moreover, doing so often is economically attractive. Initiatives for a more circular economy therefore deserve a central place in EU climate and industrial policy".

\section{Critical aspects}

The situation changes significantly across the different European states. The following figure represents the municipal waste per capita produced by 32 European Countries in the period 2001 - 2010: only 10 Countries cut the municipal waste, while 22 generated more in 2010 than in 2001. There is not a clear evidence of lower production rates across Europe, but the analysis of waste generation provides interesting insights.

Landfilling decreased of almost 40 million tonnes, incineration grew by 15 million tonnes and recycling increased of 29 million tonnes (see European Environment Agency, 2013 [7]). In particular, recycling includes composting and bioremediation and it has improved over the decade: 12 countries increased more than 10\% while other 10 increased between 5 and $10 \%$.

\footnotetext{
${ }^{9}$ See The Environmetal Literacy Council at https://enviroliteracy.org/environment-society/wastemanagement/recycling/
} 


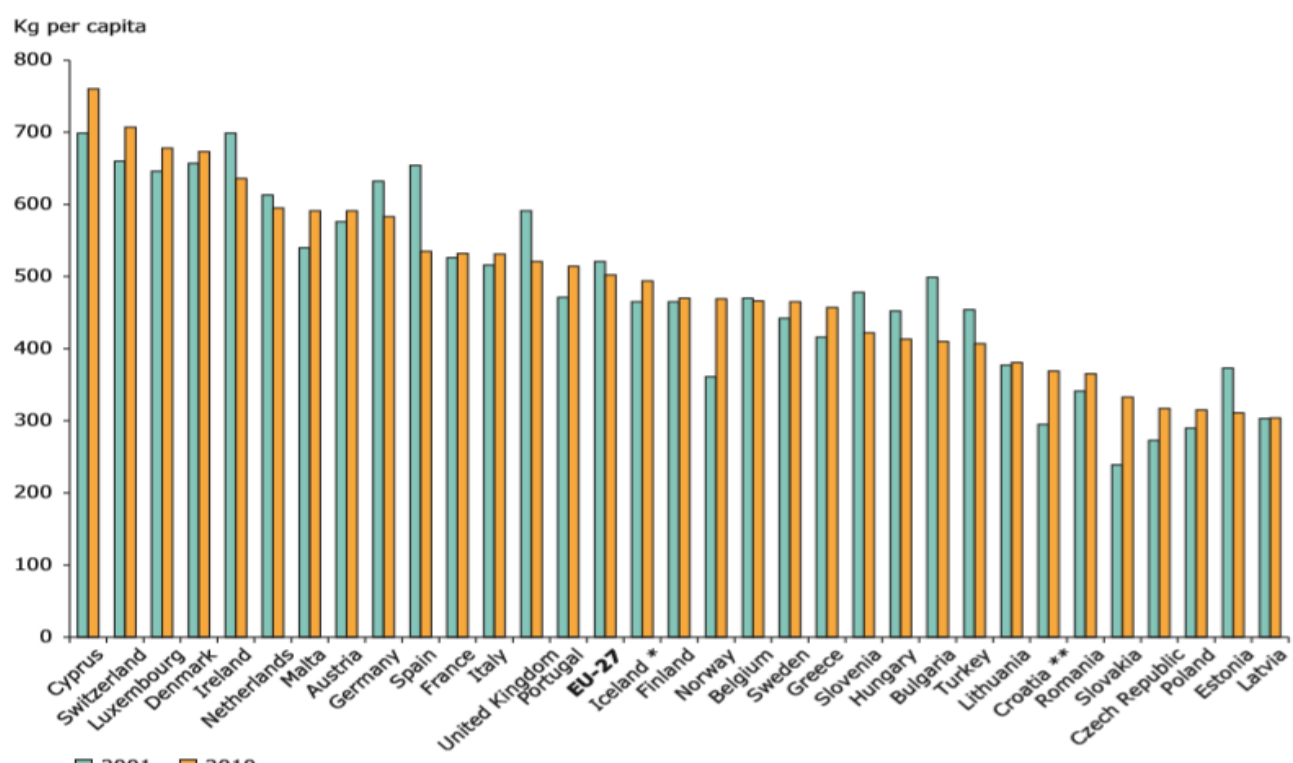

Note: (*) 2008 data used for 2010. (**) 2004 data used for 2001. According to Eurostat the comparability of the data over time is However, some breaks in the time series are documented, which can influence the comparability between countries and within a country, Generally, the quality of the data has improved during the period 2001-2010.

Source: Eurostat, 2012c; ETC/SCP, 2013b.

The next figure provides an overview of waste production in 2016. In 2016, all economic activities and households of the EU-28 produced 2,533 million tonnes of waste and the quantity of each country is related to its population and economic size: for example, Bulgaria and Romania have a relative greater quantity than Italy.

Figure 6 - Waste generation by economic activities and households in 2016

Waste generation by economic activities and households, 2016

(\%)

\begin{tabular}{|c|c|c|c|c|c|c|}
\hline & $\begin{array}{l}\text { Mining and } \\
\text { quarrying }\end{array}$ & Manufacturing & Energy & $\begin{array}{l}\text { Construction and } \\
\text { demolition }\end{array}$ & $\begin{array}{l}\text { Other economic } \\
\text { activities }\end{array}$ & Households \\
\hline EU-28 & 25 & 10 & 3 & 36 & 16 & 8 \\
\hline Belgium & 0 & 23 & 1 & 31 & 36 & 8 \\
\hline Bulgaria & 82 & 3 & 8 & 2 & 3 & 2 \\
\hline Czechia & 1 & 18 & 4 & 40 & 23 & 14 \\
\hline Denmark & 0 & 5 & 4 & 58 & 16 & 17 \\
\hline Germany & 2 & 14 & 3 & 55 & 17 & 9 \\
\hline Estonia & 26 & 37 & 25 & 5 & 6 & 2 \\
\hline Ireland (") & 18 & 23 & 2 & 12 & 35 & 10 \\
\hline Greece (') & 68 & 7 & 16 & 1 & 2 & 6 \\
\hline Spain & 16 & 11 & 3 & 28 & 26 & 17 \\
\hline France & 1 & 7 & 0 & 69 & 14 & 9 \\
\hline Croatia & 12 & 8 & 2 & 24 & 31 & 22 \\
\hline Italy & 0 & 17 & 2 & 33 & 29 & 18 \\
\hline Cyprus (') & 5 & 33 & 0 & 36 & 10 & 16 \\
\hline Latvia & 0 & 19 & 11 & 4 & 30 & 34 \\
\hline Lithuania & 1 & 41 & 2 & 8 & 32 & 17 \\
\hline Luxembourg & 0 & 7 & 0 & 75 & 11 & 6 \\
\hline Hungary & 1 & 17 & 16 & 23 & 25 & 18 \\
\hline Malta & 3 & 6 & 0 & 69 & 13 & 9 \\
\hline Netherlands & 0 & 10 & 1 & 70 & 13 & 6 \\
\hline Austria & 0 & 9 & 1 & 73 & 10 & 7 \\
\hline Poland & 39 & 17 & 11 & 10 & 18 & 5 \\
\hline Portugal & 3 & 17 & 1 & 12 & 35 & 33 \\
\hline Romania & 87 & 4 & 4 & 0 & 3 & 2 \\
\hline Slovenia & 0 & 25 & 14 & 10 & 39 & 12 \\
\hline Slovakia & 3 & 32 & 9 & 9 & 29 & 18 \\
\hline Finland & 76 & 8 & 1 & 11 & 3 & 1 \\
\hline Sweden & 77 & 4 & 1 & 7 & 7 & 3 \\
\hline United Kingdom & 6 & 4 & 0 & 49 & 30 & 10 \\
\hline Liechtenstein & 3 & $\frac{4}{2}$ & 0 & $\frac{45}{88}$ & 1 & $\frac{10}{5}+3 x-10$ \\
\hline Norway & 3 & 14 & 2 & 27 & 32 & 22 \\
\hline Montenegro & 19 & 2 & 18 & 37 & 10 & 13 \\
\hline $\begin{array}{l}\text { Former Yugoslav Republic } \\
\text { of Macedonia }\end{array}$ & 49 & 51 & 0 & 0 & 0 & 0 \\
\hline Serbia & 79 & 3 & 12 & 1 & 2 & 3 \\
\hline Turkey & 11 & & 26 & & 8 & 37 \\
\hline Kosovo* & 14 & 20 & 40 & 6 & 10 & 11 \\
\hline Bosnia and Herzegovina (2) & 2 & 27 & 71 & 0 & 0 & 0 \\
\hline
\end{tabular}

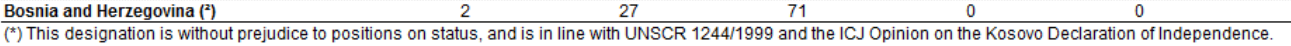

(') 2014

() 2012

Source: Eurostat (online data code: env_wasgen) 
Of these 2.533 million tonnes of waste produced, 2.309 million tonnes were treated, including the imported waste and excluding the exported waste (see Eurostat, 2018).

\section{Open challenges and possible advances}

\section{New policies for incentives and penalties.}

In many cases the objective of reaching full recyclability is anti-economic. This is often the case when the cost of the recovery is higher than the market value of the materials recovered. Current incentives provided by the regulatory body in the EU countries turn out insufficient in many cases to pursue a circular economy objective. Current incentives and tariff systems mainly focus on final consumers, waste collection and recycling utilities. However, the costs of recycling can be reduced at different steps of products life, starting from their design and the choice of materials. Therefore, the next advances of regulation should introduce a system of benefits and penalties directly at the design and production phase.

Product design making disassembly, reuse and recycling simple, will allow products to be simply and cheaply separated into their constituent products, when products have finished their life or they are sold for a reuse. To this purpose it is required that products:

- Have good design and composition records: design thinking is an innovative procedure which observes customers in their everyday lives to learn about their needs and how these are satisfied by current products. The following step is the study of a product that better satisfies customer needs by directly involving the customer.

- Have clear mechanical and reversible fixings. Between the idea and the final products, prototypes stand in the middle. They allow to study the product, simplify its mechanisms and decrease the costs and times of development because teams can work and simulate on a model.

- Are not composed of inseparable substances;

- Are of a modular size. By being modularized, goods can be recovered and reused. Furthermore, if they break people can substitute the broken module without buying an entire new product.

- Have standardised performance. By being modularized and standardized, the risk of mistakes during the production process decreases, as well as less products returned by customers, and this decreases waste as well.

- Do not containing hazardous substances.

This would also open the door to a great financial and economic opportunity, because every year $2.6 \$$ trillion worth material in fast-moving consumer goods is thrown away and not recovered (see Eric Hannon et al., 2016 [9]).

\section{Pay as you throw or door-to-door waste collection}

PAYT, door-to-door, smart bins waste collection methods provide big important progress of measuring the individual contribution to waste generation and separation. This in turn provides local authorities and waste collection utilities to distribute individual tariffs, promoting virtuous behaviour across households. However, 
it also incentivizes the despicable behaviour of abandonment of waste. Here, legislation should be introduced to prevent despicable behaviour and to formalize procedures that incentivize virtuous behaviours.

\section{Local compensations and redistribution of benefits}

The recycling activities, including separation and regeneration are not evenly distributed and clearly designed to supply local benefits. Municipalities hosting some of these services in some cases concentrate job opportunities, which mainly benefit their own citizens. In other cases recycling utilities introduce local negative impacts, like traffic and/or annoying odors, or landscape degradation. Considering the benefits of circular economy, and how it makes restored products available to people who couldn't afford it before, new regulatory instruments and compensation schemes should be introduced to distribute the benefits and mitigate the negative impacts to society.

\section{Technological difficulties and costs}

Enterprises face technical challenges when approaching the circular economy. The customers' willingness to pay for low-impact products is almost absent because they search for the cheapest alternative, without looking at the environmental impact of the product. Due to this condition, enterprises must search other ways to cut costs. One alternative is standardization: some components of a product can be standardized to reduce unnecessary variety. Variety reduction is a major help to standardize collection and recycling of many materials, such as plastic, as it turns out as direct way to reduce recycling costs.

A second alternative is low-cost technology: production processes in some industry sectors are tighten to lowest cost technologies because of hard market competition. However, the lowest cost technology is the worst from an environmental point of view is in many cases. This is where regulation can deploy its best benefit. By forcing all the competitors to adopt a new common standard, public regulation defends environment and public health, at no cost and avoiding market distortions.

Anyway, a lot still has to be done with respect to sustainability of production technologies. Given the deep differences across different sectors, there is not yet something similar to the ISO standards to fix the recommended practices to guarantee the economic - circularity of products and the sustainability of production processes.

\section{International agreements}

Countries are needed to adopt the challenge of circular economy worldwide at the same time and with similar effort to discourage producers to transfer their plants in countries where environmental costs are less strict or even absent. This threat is not new. For example, $\mathrm{CO}_{2}$ reduction regulation introduced in the EU through the ETS cap-and trade system, has introduced the additional cost of paying for every ton of $\mathrm{CO}_{2}$ emitted in the atmosphere to polluting companies. Such penalty clearly adds to the direct production costs, such as fuel, energy and raw materials. This has therefore placed an incentive to many producers, especially in the cement and the steel industries, to move their production facilities in countries where $\mathrm{CO}_{2}$ constraints are absent or less stringent. Of course, this represented a serious threat to the success of the EU-ETS system and indeed it forced the regulatory authority to distribute the emission certificates (i.e. the rights to emit 1 ton of $\mathrm{CO}_{2}$ ) for free to the polluting companies. 
Besides, successful circular economy achievements cannot be reasonably obtained by one organisation acting alone. Consider for example the case of the plastic-free campaign, which is spreading worldwide involving large shares of our societies and raising a large general concern. Packaging companies work with waste-sorting and recycling facilities, and companies involve their customers to adopt new responsible behaviour (and rewarding them when they do), but the circular economy needs good communication and collaboration to take place along the entire value chain.

\section{CONCLUSIONS}

Despite circular economy is a concept inspired by a nature principle far from economics, a lot of research has developed, both in the academic and the practical levels, and now provides large empirical evidence of the material benefits of that principle. Besides, many practical ways have appeared to translate circular economy principles into effective regulation and clear business opportunities. Consequently, economic circularity principles have become much more attractive than the concept of sustainable development, a notion not yet universally accepted for missing a satisfactory balance between environmental and economic objectives.

While many positive advances have been documented, much work is still in sight. Regulatory interventions are particularly required to distribute optimally the huge efforts required across all the actors and the sectors of our society. At the same time, it will be critical to the survival of our planet and to the success of the circular economy revolution that those principles and practices spread effectively globally.

\section{BIBLIOGRAPHY}

[1] Ritchie Hannah, Roser Max, 2018, Plastic Pollution. Available at: https://ourworldindata.org/plasticpollution

[2] Baldé, C. P., Forti, V., Gray, V., Kuehr, R., Stegmann, P., 2017, Quantities, Flows and Resources, The Global E-waste Monitor 2017.

Available at: http://ewastemonitor.info/

[3] Bonciu Florin, The European Economy: From a Linear to a Circular Economy, Romanian Journal of European Affairs, Vol. 14, N. 4, December 2014. Available at:

https://heinonline.org/HOL/LandingPage?handle=hein.journals/rojaeuf14\&div=31\&id=\&page=

[4] Chouinard Yvon, Jib Ellison, Ridgeway Rick, October 2011, The Sustainable Economy, Harvard Business Review. Available at:

https://hbr.org/2011/10/the-sustainable-economy

[5] COM 2010/235 COMMUNICATION FROM THE COMMISSION TO THE COUNCIL AND THE EUROPEAN PARLIAMENT on future steps in bio-waste management in the European Union.

[6] Directive 2008/98/EC of the European Parliament and of the Council of 19 November 2008 on waste and repealing certain Directives (Text with EEA relevance).

[7] European Environment Agency, 2013, Report n.2/2013: Managing municipal solid waste - a review of achievements in 32 European countries. 
Available at: https://www.eea.europa.eu/publications/managing-municipal-solid-waste\#tab-figures$\underline{\text { used }}$

[8] Geyer, R., Jambeck, J. R., \& Law, K. L., 2017, Production, use, and fate of all plastics ever made, Science Advances.

Available at: https://advances.sciencemag.org/content/3/7/e1700782

[9] Hannon Eric, Kuhlmann Marianne and Benjamin Thaidigsmann, 2016, Developing products for a circular economy, McKinsey \& Company. Available at:

https://www.mckinsey.com/business-functions/sustainability/our-insights/developing-products-for-acircular-economy

[10] Haque Tajirul, 2019, Introduction to Electronics (e-waste) Recycling. Available at: https://www.thebalancesmb.com/introduction-to-electronics-e-waste-recycling-4049386

[11] Jambeck, J. R., Geyer, R., Wilcox, C., Siegler, T. R., Perryman, M., Andrady, A., ... \& Law, K. L., 2015, Marine Pollution, Plastic waste inputs from land into the ocean, Science, pages 768-771.

Available at: https://www.ncbi.nlm.nih.gov/pubmed/25678662

[12] Kirchherr Julian, Laura Piscicelli, Ruben Bour, Erika Kostense-Smit, Jennifer Muller, Anne Huibrechtse-Truijens, Marko Hekkert, Barriers to the Circular Economy: Evidence from the European Union (EU), Ecological Economics, Vol. 150, pages 264-272, August 2018. Available at: https://www.sciencedirect.com/science/article/abs/pii/S0921800917317573

[13] LeBlanc Rick, 2018, An introduction to metal recycling: an overview of metal recycling, its importance, and recycling processes.

Available at: https://www.thebalancesmb.com/an-introduction-to-metal-recycling-4057469

[14] LeBlanc Rick, 2019, Quick facts about glass recycling: glass recycling facts you should know. Available at: https://www.thebalancesmb.com/facts-about-glass-recycling-2877982

[15] Material Economics, 2018, "The Circular Economy a Powerful Force for Climate Mitigation", Company report. Available at: https://materialeconomics.com/publications/the-circular-economy-apowerful-force-for-climate-mitigation-1

[16] Reinier de Man, Henning Friege, Circular Economy: European policy on shaky ground, Waste Management \& Research, Vol. 34, pages 93-95, January 2016. Available at: https://journals.sagepub.com/doi/full/10.1177/0734242X15626015

[17] Ritchie Hannah, Roser Max, 2018, Plastic Pollution.

Available at: https://ourworldindata.org/plastic-pollution

[18] Ritchie Hannah, 2018, FAQs on Plastics.

Available at: https://ourworldindata.org/faq-on-plastics\#what-are-the-environmental-impact s-of$\underline{\text { landfills }}$

[19] United Nations Department of Economics and Social Affairs, 21 June 2017, World population projected to reach 9.8 billion in 2050, and 11.2 billion in 2100. Available at: https://www.un.org/development/desa/en/news/population/world-population-prospects-2017.html 


\section{LIST OF FIGURES}

Figure 1 - Public waste generation 2010

Figure 2 - Projected share of global mismanaged plastic waste in 2025

Figure 3 - Status on separate collection of biowaste in Europe

Figure 4 - Biological cycle in the circular economy

Figure 5 - Municipal waste production per capita $(2001,2010)$

Figure 6 - Waste generation by economic activities and households in 2016 